\title{
Levansucrase of Bacillus subtilis: Efiects on the Secretion Process of Single Amino Acid Substitutions in the Mature Part of the Protein
}

\author{
By FADILA BENYAHIA, * RÉGIS CHAMBERT AND \\ MARIE-FRANÇOISE PETIT-GLATRON \\ Institut Jacques Monod, CNRS-Université Paris 7, Laboratoire Génétique et Membranes, \\ Tour 43, 2 place Jussieu, 75251 Paris Cedex 05, France
}

(Received 27 May 1988; revised 8 August 1988)

\begin{abstract}
Substitutions of an aspartate or an arginine residue for the glycine residue at position 366 of the mature part of Bacillus subtilis levansucrase were obtained by mutagenesis. Quantitative estimation from immunoblot analysis showed that the two transient membrane forms of the modified proteins were present in the membrane at the same level as that of the wild-type protein. The proteolytic processing, which was previously shown to be the first step of the levansucrase secretion process, was not affected in these modified proteins. Results from pulsechase experiments showed that the half-times for secretion of the modified levansucrases into the culture medium were nearly the same as that of the wild-type protein, but the amount of the modified proteins secreted was significantly reduced. Purified samples of the modified enzymes were subtilisin insensitive and possessed enzyme activities very similar to those of the wild-type enzyme. The results suggest that the 366 site probably belongs to a functional domain of the protein which could play an important role in the second step of the levansucrase secretion process.
\end{abstract}

\section{INTRODUCTION}

Multistep mechanisms for protein translocation have been demonstrated in prokaryotic systems (Freudl et al., 1986; Fitts et al., 1987) and have been postulated to be generally involved in protein translocation (Wickner \& Lodish, 1985). We have identified two steps in the secretion process of Bacillus subtilis QB112 levansucrase. Two transient membrane forms were demonstrated as intermediates in the levansucrase secretion pathway. The isolated membrane forms, in contrast to the exocellular form, need the presence of iron to display enzyme activity. From these results, we proposed that the release of the mature membrane form involves a conformational change, in which iron plays a role, to reach the final stable and active conformation in the culture medium (Petit-Glatron et al., 1987; Chambert \& Petit-Glatron, 1988).

The role of folding in protein transport has been reported for various prokaryotic and eukaryotic proteins (Randall \& Hardy, 1986; Maher \& Singer, 1986; Fitts et al., 1987; Park et al., 1988). Mature sequences of exported proteins contain specific structural or functional domains that play a role in secretion (Ferenci \& Silhavy, 1987). Protein fusions between functional Bacillus signal peptides and mature regions of prokaryotic or eukaryotic exported proteins have shown that secretion efficiency is greatly influenced by the nature of the mature protein sequence, suggesting that the presence of a leader peptide is not always the sole requirement for secretion of normal levels of protein (Himeno et al., 1986).

Mutational alterations, by site-directed mutagenesis, provide a useful tool for identifying structural features of mature sequences that affect translocation efficiency. In the case of

Abbreviations: PMSF, phenylmethylsulphonyl fluoride; U, unit of enzyme activity. 
levansucrase, our study of two charged amino acid substitutions started from the following considerations. Firstly, the second step of levansucrase secretion depends on the membrane potential (Chambert \& Petit-Glatron, 1988). Thus, substitution of a neutral amino acid by a positively or negatively charged one will alter the global charge of levansucrase and may result in a modification in the membrane/protein interaction, with consequential effects on the sequential events in the secretion process as well as on enzyme activity. Secondly, a $B$. subtilis mutant modified in its levansucrase secretion process was obtained by Le Coq et al. (1984). Steinmetz et al. (1985), who have sequenced the structural wild-type sac $B$ gene in our laboratory, have localized at least one mutation in this mutant, which corresponded to a substitution by an aspartate residue of the glycine residue at position 366 of the mature sequence. Furthermore, this residue was localized in a region of low secondary structure probability (Lebrun, 1980).

In this study, a unique negatively charged substitution was obtained by the exchange of the DNA fragment coding for the identified asparate mutation at residue 366 for the corresponding wild-type fragment. A positively charged arginine residue was introduced at the same site by oligonucleotide-directed mutagenesis. We describe the effects of opposite charge at the same site of the C-terminal part of the protein on the two-step secretion mechanism and the enzymic properties of the modified proteins.

\section{METHODS}

Bacterial strains and plasmids. Escherichia coli 71.18 [ $\triangle\left(\right.$ lac-proAB) thi supE $\left(\mathrm{F}^{\prime}\right.$ proAB lack $\left.\left.{ }^{\prime} Z \Delta M 15\right)\right]$ was used as a host for the construction of plasmids. BF151, BF211-D and BF311-R (this work) are strains of Bacillus subtilis constructed from $B$. subtilis CarlaII strain and the integration of plasmids píS151, pLS211-D and pLS311-R, respectively, as described below. B. subtilis QB112 is a sac $U^{\mathrm{h}}$ levansucrase-hyperproducing strain (Kunst et al., 1974).

Isolation of the mutant strains. (i) Substitution of Gly ${ }_{366} \rightarrow$ Asp in the sacB gene: construction of pLS211-D. The Gly $_{366} \rightarrow$ Asp substitution came from pLS111, a derivative of pLS50 (Steinmetz et al., 1983) obtained previously by in vitro chemical mutagenesis (Le Coq et al., 1984). The export of pLS111-encoded levansucrase, expressed in an $E$. coli minicell system, was altered in comparison to that of the protein encoded by pLS50. A mutation was localized by genetic mapping of the 3 -end region of $\operatorname{sacB}$ and by DNA sequencing of the pLS111 KpnI-HindIII fragment. The GGC codon $\left(\mathrm{Gly}_{366}\right.$ ) was changed to GAC, which corresponds to an aspartate residue. The KpnI-HindIII fragment of pLS111 was isolated and exchanged with the wild-type fragment of pLS151 (Steinmetz et al., 1985). Thus, pLS211-D, the resultant plasmid, contains a single mutation (GGC $\rightarrow$ GAC).

(ii) Substitution of Gly $y_{366} \rightarrow$ Arg in the sacB gene by site-directed mutagenesis: construction of pLS311-R. The Gly $_{366} \rightarrow$ Arg substitution was obtained by oligonucleotide-directed mutagenesis using a 27-mer synthetic oligonucleotide ( ${ }_{3}$ GGTAAAAATTGTGTTCCGCTCAAAACA ${ }_{s}$ ). The oligonucleotide-directed mutagenesis was done on the KpnI-HindIII fragment of the sacB gene of pLS151 subcloned into pTZ18R, a pUC derivative (Vieira \& Messing, 1982). Recombinant pTZ18R was converted into single-stranded DNA by superinfection with a helper phage M13KO7 according to the procedure of Dente et al. (1985). Annealing between the single-stranded DNA and the mutagenic oligonucleotide, elongation, and ligation were done as described by Zoller \& Smith (1984). The mutant colonies were screened by hybridization with labelled mutagenic oligonucleotide. The mutation was confirmed by DNA sequencing (Sanger $e$ t al., 1980). The mutant KpnI-HindIII fragment was reintroduced into pLS151, to give the recombinant plasmid pLS311-R.

(iii) Integration of plasmids in B. subtilis CarlalI strain. B. subtilis CarlaII strain (amyE $E^{+} \operatorname{sacB}$ sac $U^{\text {h } 32)}$ (Levin et al., 1985) was used as a host strain for the integration into the chromosome, by homologous recombination, of plasmids pLS151, pLS211-D and pLS311-R; all are derivatives of pJH101 which cannot replicate in $B$. subtilis. This strain lacks a functional $\operatorname{sac} B$ gene as a result of the integration of a hybrid levansucrase-amylase gene from pGGI into the chromosomal sacB gene. The $3^{\prime}$ and $5^{\prime}$ ends of sacB gene allow the integration, by double crossingover, of plasmids containing a sac $B$ gene, leading to a deletion of the $\alpha$-amylase gene. Transformants were selected on plates of LB medium containing $3 \mu \mathrm{g}$ chloramphenicol $\mathrm{ml}^{-1}$. The deletion of the $\alpha$-amylase gene was confirmed by the absence of $\alpha$-amylase activity using starch iodine staining (Coleman \& Elliott, 1962) on plates. The strains containing pLS151, pLS211-D and pLS311-R integrated into the chromosome were called BF151, BF211-D and BF311-R, respectively.

Quantification of membrane forms of levansucrase. Cells were grown at $37^{\circ} \mathrm{C}$ in the medium previously described (Petit-Glatron et al., 1987). The preparation and the quantification of membrane forms of levansucrase were done as described by Petit-Glatron et al. (1987).

Pulse-labelling experiments. Cultures of $B$. subtilis strains BF151, BF211-D and BF311-R at an $O_{650}$ of 0.5 were induced by adding sucrose and continuing growth for $90 \mathrm{~min}$ at $30^{\circ} \mathrm{C}$. Cells were then pulse-labelled by adding 
$0.15 \mathrm{mCi}(5.55 \mathrm{MBq})$ [ $^{35}$ Slmethionine $\left(800 \mathrm{Ci} \mathrm{mmol}^{-1} ; 29.6 \mathrm{TBq} \mathrm{mmol}^{-1}\right)$ to $1.5 \mathrm{ml}$ of the culture suspension, maintained at $30^{\circ} \mathrm{C}$. After a pulse period of $30 \mathrm{~s}$, non-radioactive methionine (final concentration $2 \mathrm{~mm}$ ) was added. Samples $(200 \mu \mathrm{ll})$ were removed at various times and all reactions were stopped by diluting the samples fivefold with ice-cold phoephate buffer (0.1 M-potassium phosphate buffer $\mathrm{pH} \mathrm{7.0,} \mathrm{containing} 2 \mathrm{M}-\mathrm{KCl}, 200 \mu \mathrm{g}$ chloramphenicol $\mathrm{ml}^{-1}, 5 \mathrm{mu}$-EDTA and $0.2 \mathrm{mu}$-PMSF). The cell suspensions were then centrifuged. The supernatants were diluted in 0.1 M-potassium phosphate buffer $\mathrm{pH} 7.0$, containing $0.1 \%$ bovine serum albumin and $0.5 \%$ Triton X-100. They were incubated overnight in the presence of antibodies against purified exocellular levansucrase coupled to glutaraldehyde-activated Ultrogel (Act Ultrogel AcA 22, IBF). Immunoprecipitates were recovered, washed with the dilution buffer and solubilized by heating for $5 \mathrm{~min}$ at $95^{\circ} \mathrm{C}$ in electrophoresis sample buffer.

Gel electrophoresis and immunoblotting. SDS-PAGE, immunoblotting on nitrocellulose sheets $(0.45 \mu \mathrm{m}$ pore size) and subsequent incubation with purified anti-levansucrase antibodies and radio-iodinated protein $\mathbf{A}$ were performed as described previously (Petit-Glatron et al., 1987). Quantitative analysis of levansucrase radioactive spots was done by slicing the nitrocellulose, using the autoradiogram as a visual guide, and measuring radioactivity in a liquid scintillation counter. To determine the amount of levansucrase in the samples, a standard curve was established from immunoblotting of purified levansucrase, within the range 5-40 ng. These values were plotted versus the corresponding radioactivity.

Purification of exocellular levansucrase. Cultures of $B$. subtilis strains BF211-D, BF311-R and QB112 at an OD $_{650}$ of 0.5 were induced by adding sucrose and continuing incubation for $3 \mathrm{~h}$. Except for cultures of strain QB112, the protease inhibitor PMSF ( $5 \mathrm{mM}$ ) was added $5 \mathrm{~min}$ after the start of the induction period. The cell suspensions were centrifuged. The culture supernatant of each strain was pooled with the $\mathrm{KCl}$ supernatant obtained by washing the cells with cold potassium phosphate buffer containing $2 \mathrm{M}-\mathrm{KCl}$ and protease inhibitors (PMSF and EDTA). Exocellular levansucrase was purified by hydroxyapatite chromatography of the culture supernatant (Chambert et al., 1974):

Assay of levansucrase activity. Levansucrase of $B$. subtilis catalyses, in vitro, the following reactions: sucrose hydrolysis, levan polymerization and glucose exchange. The various levansucrase activities were evaluated by measuring the initial velocity of each reaction as described by Chambert et al. (1974).

\section{RESULTS}

\section{Confirmation of the mutations by DNA sequencing}

The procedure for the isolation of the mutant strains is described in Methods. The DNA nucleotide sequences of subcloned KpnI-HindIII fragments of pLS211-D and pLS311-R, compared to the KpnI-HindIII fragment of pLS151, confirm that the glycine codon (GGC) has been changed to an aspartate codon (GAG) or an arginine codon (CGC) (Fig. 1).

\section{Levansucrase production in the mutant strains compared to the wild-type strain}

The wild-type reference strain used in this study was B. subtilis BF151, obtained as described in Methods. The absence of levansucrase synthesis in non-induced cultures of both the reference strain and the mutants was confirmed by immunoblot analysis (not shown). Total production of levansucrase (i.e. cell-bound activity and activity released into the supernatant) in exponentially growing bacteria fully induced by $50 \mathrm{~mm}$-sucrose was determined for each strain. The differential rate of levansucrase synthesis of the wild-type strain was estimated to be $1.5 \mathrm{U}$ per $\mathrm{OD}_{650}$ unit at $30^{\circ} \mathrm{C}$, the same as that of the $\operatorname{sac} U^{\mathrm{h}}$ strain $\mathrm{QB112}$ grown under identical conditions (R. Chambert \& M.-F. Petit-Glatron, unpublished results). The differential rates of levansucrase synthesis of mutants BF211-D and BF311-R were, respectively, 0.02 and 0.01 U per $\mathrm{OD}_{650}$ unit at $30^{\circ} \mathrm{C}$, i.e. $1.5 \%$ and $<1 \%$ of the wild-type value. Thus, the additional positive or negative charge on the protein molecule caused a significant decrease in the total production of functional levansucrase. We further examined each step of the secretion process, in order to determine the stage (i.e. synthesis and/or secretion) at which these mutants are perturbed.

\section{Effect of the substitutions Gly ${ }_{366} \rightarrow$ Asp and Gly $_{366} \rightarrow$ Arg on the synthesis of intermediate membrane forms of levansucrase and on the processing of the precursor forms}

The effect of a negatively charged (Asp) or a positively charged (Arg) residue substituted for Gly $_{366}$ on the first step of the secretion process of levansucrase was evaluated by comparison of the amount of the two transient membrane forms of levansucrase produced in mutant strains 


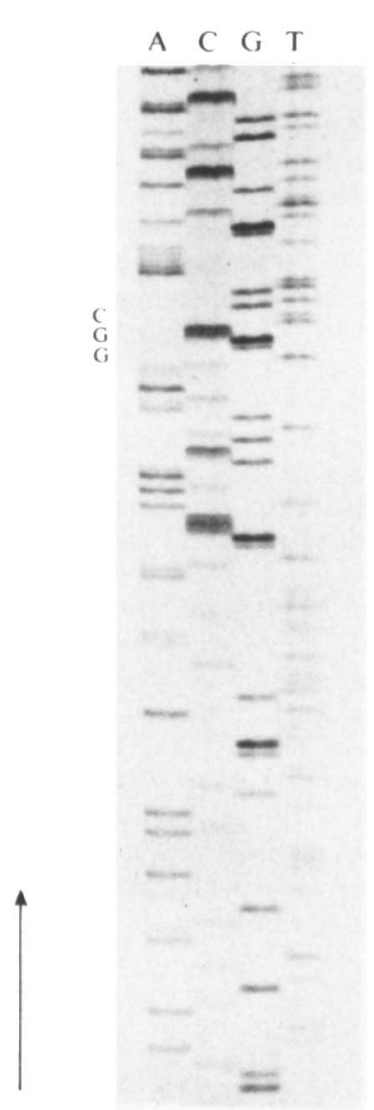

(a)

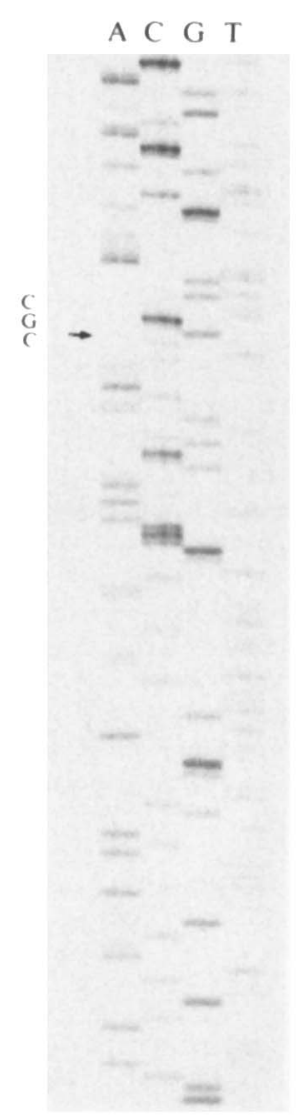

(b)

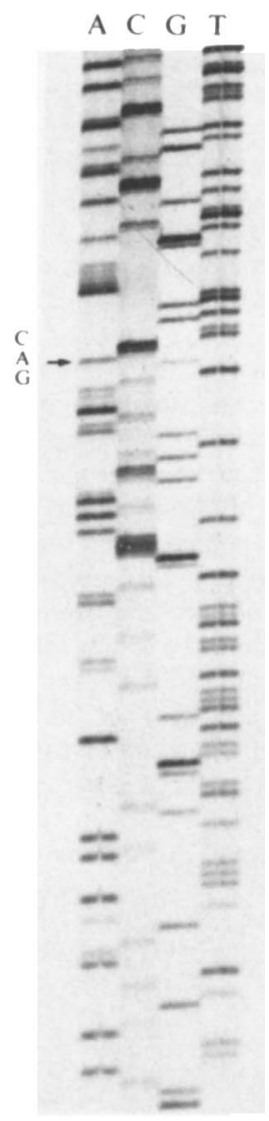

(c)

Fig. 1. Confirmation of the mutations by DNA sequencing. The subcloned KpnI-HindIII fragments of pLS151, pLS211-D and pLS311-R were converted to single-stranded DNA as described in Methods. M13 reverse sequencing primer (AACAGCTATGACCATG), hybridizing 44 bases upstream of the beginning of the KpnI-HindIII fragment in pTZ18R, was used to start DNA synthesis. DNA nucleotide sequencing was performed according to Sanger $e t$ al. (1980). The GGC wild-type codon (a) becomes a CGC codon (arginine residue) in pLS311-R (b), and a GAC codon (aspartate residue) in pLS211-D (c). The small arrows indicate the base change and the large arrow indicates the direction of DNA synthesis.

and the wild-type reference strain. We have previously demonstrated that an agent, such as ethanol, which modifies membrane fluidity is a modulator of this step (Petit-Glatron et al., 1987). A high concentration of ethanol ( $1.5 \mathrm{M})$ inhibited the proteolytic processing of the precursor form of levansucrase. In each strain the amount of intermediate membrane forms was evaluated by immunoblot analysis in the presence and in the absence of ethanol (Fig. 2). In the absence of ethanol, all three strains produced the same quantities of the $53000 M_{\mathrm{r}}$ form and of the $50000 M_{\mathrm{r}}$ form. The amounts of the larger and the smaller membrane form were evaluated by quantitative immunoblot analysis as, respectively, 35 and $130 \mathrm{ng}$ per $\mathrm{OD}_{650}$ unit of culture. For each strain, the amount of the $53000 M_{\mathrm{r}}$ membrane form was increased six-fold after incubation for $10 \mathrm{~min}$ in the presence of $1.5 \mathrm{M}$-ethanol. The presence of smaller polypeptides observed only in the BF211-D and BF311-R strains (Fig. 2) may indicate a protease sensitivity of the modified levansucrases.

These results suggest that the two intermediate forms of levansucrase were synthesized in the mutants at the same level as in the wild-type. The fact that the processing of the precursor form 


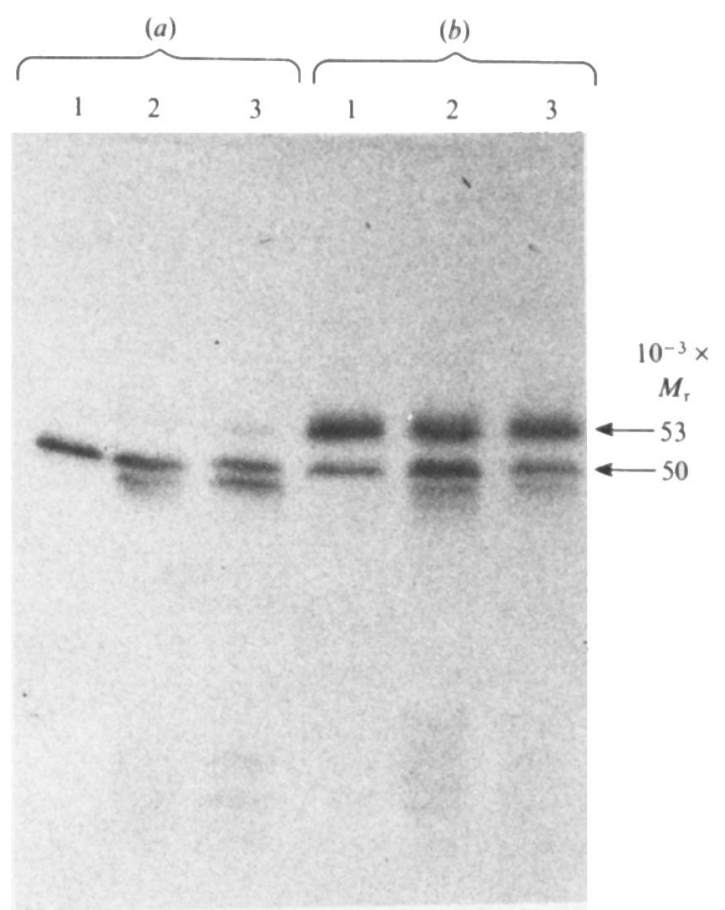

Fig. 2. Production of cell-associated forms of levansucrase, in the absence and in the presence of ethanol, by the mutant strains and by the wild-type reference strain. Cell suspensions at an $\mathrm{OD}_{650}$ of 0.5 were induced for levansucrase synthesis by adding 50 mu-sucrose. After $90 \mathrm{~min}$, each culture was divided equally and one part was incubated in the presence of 1.5 M-ethanol for $10 \mathrm{~min}$; then $5 \mathrm{ml}$ of each cell suspension was withdrawn and treated as described in Methods. SDS-PAGE, and subsequent immunoblot anatysis, were carried out on the same amount of lysed cells. (a) Cells not treated with ethanol; (b) cells treated with ethanol. Lanes 1, 2 and 3 represent the membrane forms of levansucrase obtained from cells of the wild-type reference strain, from mutant BF211-D and from mutant BF311-R, respectively. The positions of the $53000 M_{\mathrm{r}}$ and the $50000 M_{\mathrm{r}}$ membrane forms are indicated.

of the modified proteins was not inhibited suggests that the modified proteins were affected in the second step of the secretion pathway. Pulse-chase experiments allowing the determination of kinetic parameters of levansucrase release were used to study the second step.

\section{Effect of the point mutations on the second step of levansucrase secretion}

The differences in the half-lives of the two membrane forms (4-5 s for the $53000 M_{\mathrm{r}}$ form, versus $32-42 \mathrm{~s}$ for the $50000 M_{\mathrm{r}}$ form) and the correlation between the disappearance of the $50000 M_{\mathrm{r}}$ membrane form and the appearance of exocellular form allow the experimental study of the second step (Chambert \& Petit-Glatron, 1988). 'Exocellular form', as used previously, is the levansucrase released in the culture medium plus the levansucrase released by washing the cells at high ionic strength. During the exponential phase of growth, induced cells of both strain BF151 (not shown) and strain QB112 (Chambert \& Petit-Glatron, 1984) secreted only levansucrase.

The decrease of total levansucrase production in the mutant strains could result from a modification of the second step of levansucrase secretion and/or from proteolysis in the culture medium. Therefore, pulse-chase experiments were done in the presence and in the absence of the protease inhibitor PMSF. Cultures were grown for one generation time in the presence of 5 mM-PMSF, added to the culture medium after induction of levansucrase synthesis. This concentration of PMSF did not affect cell growth. Fig. 3 shows the kinetics of secretion, analysed for each strain grown in the absence of PMSF. In both mutants a great decrease in the 

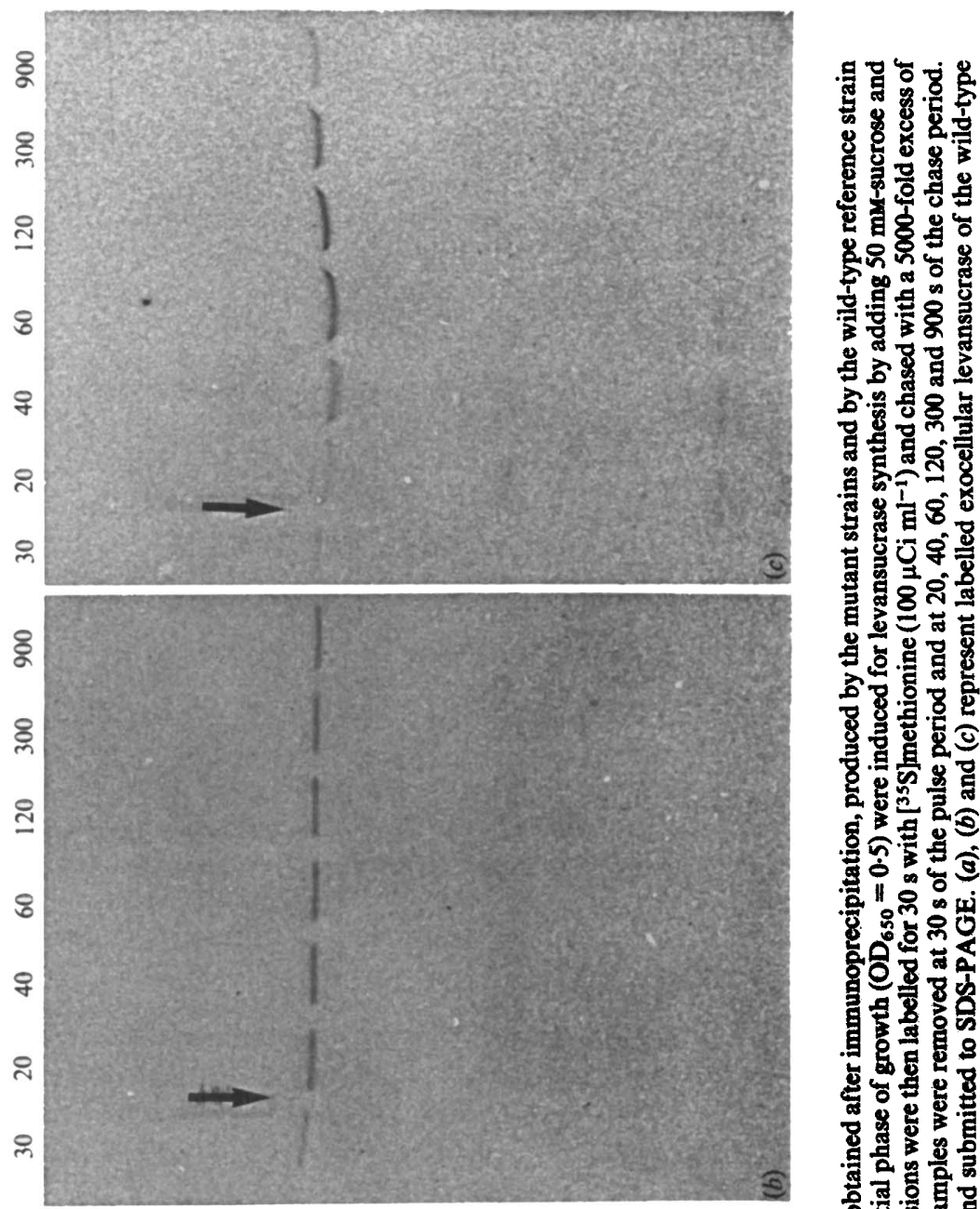

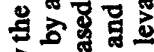
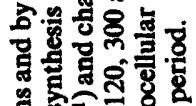

a

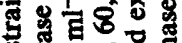

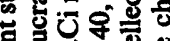

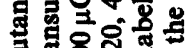

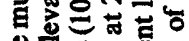

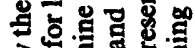
死 8

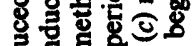

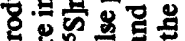
2.

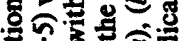
要 웅 8 80 青学 貝

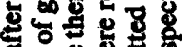
용

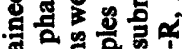
구을
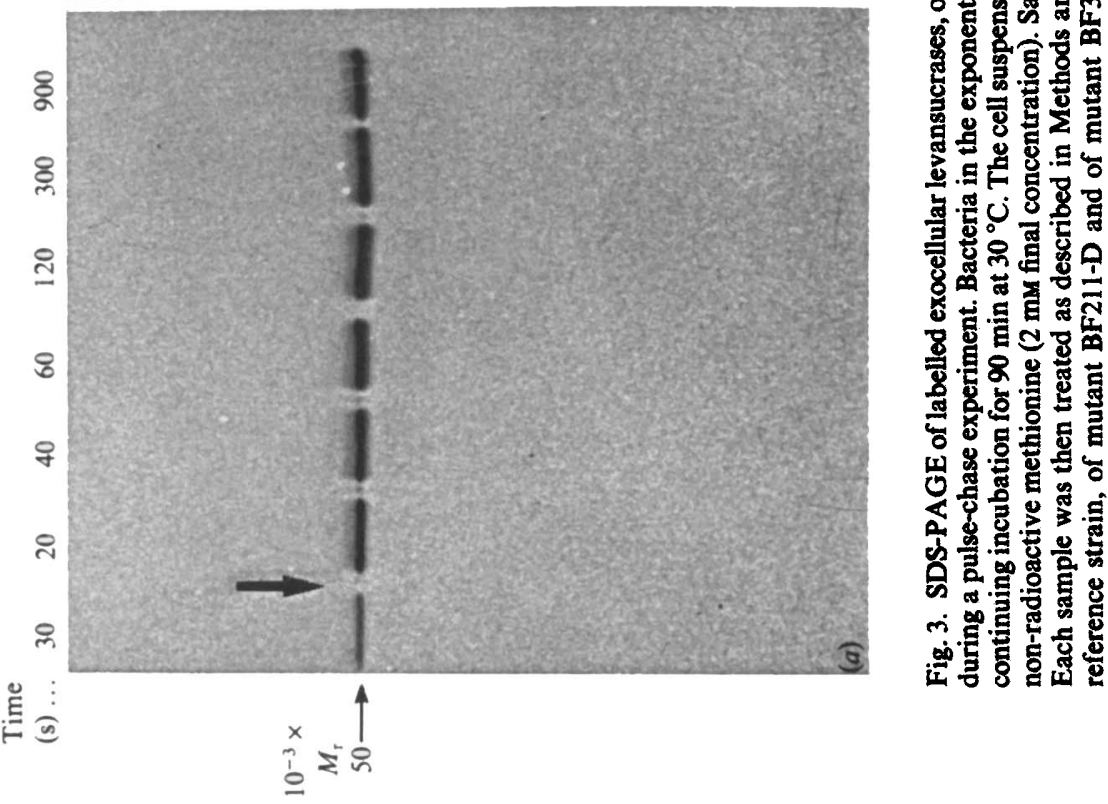

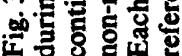




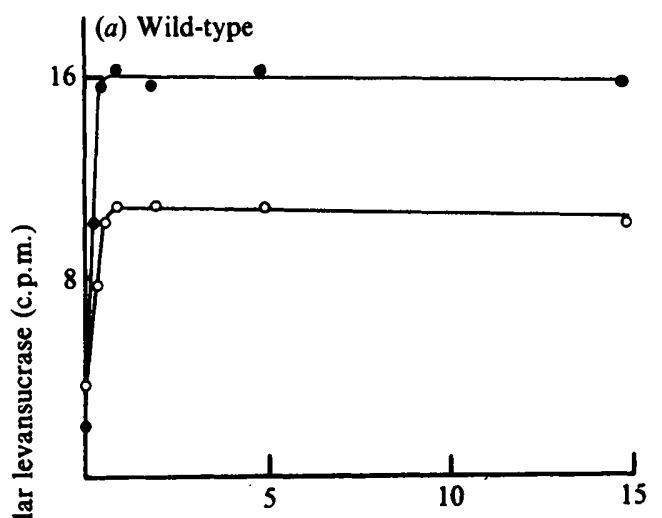

Fig. 4. Kinetics of levansucrase release into the culture medium: quantitative analysis of pulse-chase experiments with cells grown in the presence and in the absence of PMSF. Pulse-chase experiments, as described in Fig. 3, were carried out on cell suspensions grown in the absence (O) or in the presence of $5 \mathrm{~mm}$-PMSF (O). PMSF was added $60 \mathrm{~min}$ after levansucrase induction, and incubation continued for one generation. Quantitative analysis of radioactive spots was done by slicing the dry gel and measuring radioactivity in a liquid scintillation counter. (a), (b) and (c) represent, respectively, the quantitative analysis of kinetics of exocellular levansucrase release from the wild-type reference strain, from mutant BF211-D and from mutant BF311-R.

(b) Mutant BF211-R

(c) Mutant BF311-R
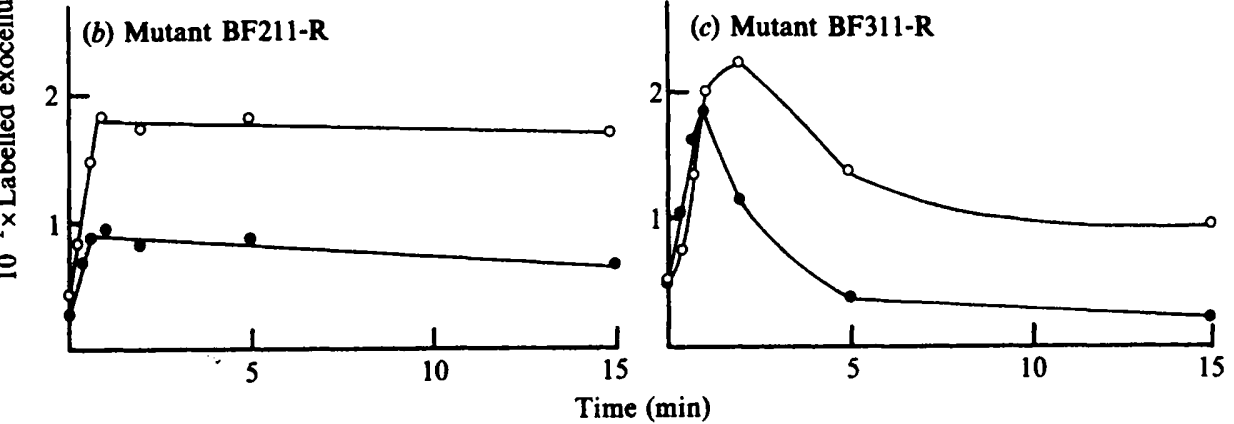

amount of modified secreted levansucrases, in comparison with the amount secreted by the wildtype reference strain, was observed. The kinetics of exocellular levansucrase production were examined further by quantitative analysis. The amounts of labelled levansucrase recovered for each strain in the presence and in the absence of PMSF are presented in Fig. 4. From these curves, the half-times of levansucrase released in the mutant strains, in the presence and the absence of PMSF, were roughly the same as in the wild-type (20-30 s). In the absence of PMSF, the maximal amount of exocellular protein produced by strains BF211-D and BF311-R represented, respectively, $5 \%$ and $11 \%$ of that of the wild-type, but in strain BF311-R this value decreased rapidly and stabilized at about $2 \%$. These values are in the same order of magnitude as that found for the production of active enzymes and given above.

A lower level of levansucrase secretion was observed in the wild-type reference strain in the presence of PMSF. This was attributed to the presence of ethanol, used to solubilize PMSF. The final concentration of ethanol $(0.17 \mathrm{M})$ added to the culture medium slightly decreased the differential rate of levansucrase synthesis, as was reported by Petit-Glatron \& Chambert (1981). The addition of PMSF increased the level of levansucrase secretion of mutant BF211-D strain twofold; with mutant BF311-R, PMSF slightly increased the production of exocellular levansucrase in the first few minutes, after which the secreted enzyme stabilized at a level two- to threefold higher (Fig. 4). The decrease of the modified levansucrase in the supernatant of strain BF311-R was correlated with the appearance of degraded products (faint bands in Fig. 3c). However, the instability of the released proteins in the culture medium, in the presence or in the absence of PMSF, is relatively small and does not account for the lower quantity of levansucrase secreted by the mutants. These results indicate that both mutant strains secreted only a reduced fraction of the $50000 M_{\mathrm{r}}$ membrane form.

Comparison of the enzymic properties of purified modified and wild-type exocellular levansucrases

The enzymic parameters of the three transfructosylation reactions - glucose exchange, sucrose hydrolysis and levan polymerization - for purified samples of modified and wild-type 
Table 1. Enzymic parameters of purified wild-type and modified levansucrases

Purification and determination of the enzymic parameters were done as described in Methods.

\begin{tabular}{|c|c|c|c|c|c|}
\hline \multirow[b]{2}{*}{$\begin{array}{l}\text { Source of purified } \\
\text { levansucrase }\end{array}$} & \multicolumn{3}{|c|}{$10^{2} \times$ Specific activity $\left[\mathrm{U}(\mathrm{mg} \text { protein })^{-1}\right]^{*}$} & \multicolumn{2}{|c|}{ Yield of levans $(\%)$} \\
\hline & $\begin{array}{l}\text { Exchange } \\
\text { reaction }\end{array}$ & $\begin{array}{c}\text { Sucrose } \\
\text { hydrolysis }\end{array}$ & $\underset{\text { polymerization }}{\text { Levan }}$ & $\begin{array}{l}\text { - levan } \\
\text { acceptor }\end{array}$ & $\begin{array}{l}\text { +levan } \\
\text { acceptor }\end{array}$ \\
\hline Wild type & 50 & 3.96 & $1 \cdot 28$ & 32 & 99 \\
\hline $\begin{array}{l}\text { Mutant } 211-\mathrm{D} \\
\left.\quad \text { (Gly }_{366} \rightarrow \text { Asp }\right)\end{array}$ & 130 & $7 \cdot 9$ & 1.73 & 22 & 92 \\
\hline $\begin{array}{l}\text { Mutant } 311-R \\
\text { (Gly }_{366} \rightarrow \text { Arg) }\end{array}$ & 60 & 3.45 & 0.8 & 23 & 99 \\
\hline
\end{tabular}

exocellular levansucrases are shown in Table 1. Exocellular levansucrase produced by strain QB112 was used as a reference.

Small differences were observed between the specific activities of the three levansucrases for each transfructosylation reaction. The modified levansucrase from mutant BF211-D appeared to be slightly more active than the wild-type. Both modified levansucrases gave a low yield of levan polymerization compared to the wild-type enzyme, in the absence of levan acceptor. No difference was observed in the activity measured by the glucose exchange reaction in the presence or in the absence of subtilisin $\left(50 \mu \mathrm{g} \mathrm{ml}^{-1}\right)$ for any of the purified levansucrases.

\section{DISCUSSION}

The modification of the net charge of levansucrase obtained by a single amino acid change in its C-terminal region dramatically decreased the capacity of $B$. subtilis to secrete this protein. The modifications studied affected the net charge of levansucrase by $16 \%$; even with the Gly $_{366} \rightarrow$ Arg substitution, the molecule is negative at physiological $\mathrm{pH}$. The net charge of the proteins was calculated from their composition and the $\mathrm{pK}$ values of free amino acids. Pulselabelling experiments clearly indicated that it is the efficiency of the second step of the process of levansucrase secretion which is disturbed by these charge modifications. Seemingly the halftime of this cellular event remains unchanged but the yield of secretion of the processed membrane form of the enzyme is strongly decreased.

We recently demonstrated (Chambert \& Petit-Glatron, 1988) that the second step of levansucrase secretion has the properties of a membrane-active transport system. How is the net charge of the protein involved in this process?

Modifications of protein stability resulting from a single amino acid change in the primary sequence of the protein have been described in several recent cases (Yutani et al., 1987; Schultz et al., 1987). Both amino acid substitutions in the levansucrase sequence modify the stability of this exocellular protein to various degrees. The additional positive charge gave the least stable protein under the conditions of temperature and $\mathrm{pH}$ pertaining in the culture medium. Protease sensitivity or thermal instability may explain the protein instability observed. However, in the conditions of the enzyme assays the purified modified levansucrases remained stable and active in the presence of subtilisin. The enzymic parameters were very similar to those of the wild-type enzyme. These results suggest that both amino acid substitutions have at most a rather small effect on the final tertiary conformation of levansucrase.

Several hypotheses may be evoked to explain the low level of secretion of the modified proteins into the exocellular medium. We have proposed previously that the mature membrane form needs to undergo a conformational change to be released into the exocellular medium in the stable and active form; iron seems to be involved in this folding step (Petit-Glatron et al., 1987; Chambert \& Petit-Glatron, 1988). We further proposed that the mature membrane form may be 
present in two intermediate species in the membrane fraction, an unfolded form being converted into a folded form. The folded form would be the only form that can be released into the culture medium. The amino acid substitution in the modified levansucrases may decrease the transition rate of unfolded to folded membrane form. This folding step therefore constitutes the rate-limiting step in the secretion process of levansucrase. The unfolded protein should be protease sensitive, as suggested by the absence of accumulation of the mature membrane form and the presence of small polypeptides in the cellular fraction. Thus, competition between proteolysis and folding of the membrane form of levansucrase could explain the discrepancy observed for the yield of secretion.

Another hypothesis is that the amino acid substitutions reduce the affinity of levansucrase for a membrane component involved in the secretion apparatus. Only the fraction associated with this hypothetical component would be protected from protease attack and be released in the culture medium. The product of the sacU gene may be a candidate for this membrane component. sac $U$ mutations are pleiotropic and modulate the level of synthesis and secretion of at least five exoproteins (levansucrase, $\beta$-glucanase, $\alpha$-amylase, serine protease and neutral protease) and affect several membrane related functions (Kunst et al., 1974). The transcriptional effect of sacU (Aymerich et al., 1986; Shimotsu \& Henner, 1986) may partially explain the level of levansucrase synthesis in a sac $U$ mutant, but no experimental data are available to elucidate how the export apparatus is exclusively used to secrete levansucrase during the exponential phase of growth (Chambert \& Petit-Glatron, 1984). The cloning and the identification of the product of $s a c U$ may help to clarify the nature of the secretion apparatus in B. subtilis.

Recent evidence from several laboratories suggests that the dynamics of protein folding governs translocation across the membrane in prokaryotic and eukaryotic systems (Randall \& Hardy, 1986; Maher \& Singer, 1986; Eilers \& Schatz, 1986). The role of levansucrase folding during translocation across the membrane is currently being investigated by studies in vitro of the kinetics of the unfolding/folding transition of purified wild-type and modified levansucrases. Purification of large amounts of modified levansucrases and the construction of other modified levansucrases are in progress.

We are grateful to Michel Steinmetz for the gift of pLS plasmids and Bacillus subtilis Cariall strain. We are indebted to Dr H. Hassan (North Carolina State University at Raleigh) for reading the manuscript.

\section{RBFERENCES}

A MMerich, S., GonzY-Treboul, G. \& StennMatz, $M$. (1986). $5^{\prime}$-Noncoding region $\operatorname{sac} R$ is the target of all identified regulations affecting the levansucrase gene in Bacillus subtilis. Joumal of Bacteriology 166, 993-998.

Chamabrt, R. \& PettT-Glatron, M. F. (1984). Hyperproduction of exocellular levansucrase by Bacillus subtilis: examination of the phenotype of a sac $U^{\text {h }}$ strain. Joumal of General Microbiology 130, 3143-3152.

Chambert, R. \& Pettr-Glatron, M. F. (1988). Secretion mechanism of Bacillus subtilis levansucrase: characterization of the second step. Journal of General Microbiology 134, 1205-1214.

Chumbert, R., Trebour, G. \& DedondBR, R. (1974). Kinetic studies of levansucrase of Bacillus subtilis. European Journal of Biochemistry 41, 285-300.

Colmman, G. \& ElliotT, W. H. (1962). Studies on $\alpha$ amylase formation by Bacillus subtilis. Biochemical Journal 83, 256-263.

Dente, L., Sollazzo, M., Baldari, C., Cesareni, G. \& CORTESE, R. (1985). The pEMBL family of singlestranded vectors. In DNA Cloning, a Practical Approach, pp. 101-107. Edited by D. M. Glover. Oxford \& Washington DC: IRL Press.
Enlses, M. \& Schurz, G. (1986). Binding of a specific ligand inhibits import of a purified precursor protein into mitochondria. Nature, London 322, 228-232.

FrRenCI, T. Silhavy, T. J. (1987). Sequence information required for protein translocation from the cytoplasm. Journal of Bacteriology 169, 5339 5342.

FitTs, R., Reuveny, Z., Van Amstbrday, J., MULHOLLAND, J. \& BOTSTEIN, D. (1987). Substitution of tyrosine for either cysteine in $\beta$-lactamase prevents release from the membrane during secretion. Proceedings of the National Academy of Sciences of the United States of America 84, 8540-8543.

FrbUd, R., SChWarz, H., StuBrhor, Y. D., GaMon, K., HINDENNACH, I. \& HENNING, U. (1986). An outer membrane protein (OmpA) of Escherichia coli K12 undergoes a conformational change during export. Joumal of Biological Chemistry 261, 11355-11361.

Homeno, T., Imanaka, T. \& Aiba, S. (1986). Protein secretion in Bacillus subtilis as influenced by the combination of signal sequence and the following mature portion. FEMS Microbiology Letters 35, 17-21.

Kunst, F., Pascal, M., Lepesunt-Kejzilarova, J., Lepesant J. A., Billault, A. \& Dedondre, R. 
(1974). Pleiotropic mutations affecting sporulation conditions and the syntheses of extracellular enzymes in Bacillus subtilis 168 . Biochimie 56, 14811489.

LBBRUN, E. (1980). Structure tridimensionnelle de la lévane saccharase de Bacillus subtilis à $3,8 A$ de résolution. Thèse de Doctorat, Université Paris VI.

le CoQ, D., Ratet, P., Steindetz, M. \& Gay, P. (1984). A genetic approach to levansucrase secretion in Bacillus subtilis. In Genetics and Biotechnology of Bacilli, pp. 141-152. Edited by A. T. Ganesan \& J. A. Hoch. Academic Press: New York.

LeVIN, D., JOYET, P., LOUVBnCOURT, L., AYMERICH, S., Le Reverend, B., Steinmetz, M. \& Heslot, $H$. (1985). Vecteurs d'expression de l' $\alpha$-amylase dans Bacillus subtilis, souches obtenues et procédé de préparation d' $\alpha$-amylase. Brevet no. 2582316 . Institut National de la Propriété Industrielle, Paris.

MAHER, P. A. \& SINGerR, S. J. (1986). Disulfide bonds and the translocation of proteins across membranes. Proceedings of the National Academy of Sciences of the United States of America 83, 9001-9005.

Park, S., LIU, G., ToppIng, T. B., Cover, W. H. \& RANDALL, L. L. (1988). Modulation of folding pathways of exported proteins by the leader sequence. Science 239, 1033-1035.

Pettr-Glatron, M. F. C Chambert, R. (1981). Levansucrase of Bacillus subtilis: conclusive evidence that its production and export are unrelated to fatty-acid synthesis but modulated by membranemodifying agents. European Journal of Biochemistry $119,603-611$.

Pettr-Glatron, M. F., Benyahia, F. \& Chambirt, R. (1987). Secretion of Bacillus subtilis levansucrase: a possible two-step mechanism. European Journal of Biochemistry 163, 379-387.

RANDALL, L. L. \& HARDY, S. J. S. (1986). Correlation of competence for export with lack of tertiary structure of the mature species: a study in vivo of maltose-binding protein in Escherichia coli. Cell 46, 921-928.

Sanger, F., Coulson, A. R., Barrell, B. G., Smith, A. J. H. \& ROE, B. A. (1980). Cloning in single- stranded bacteriophage as an aid to rapid DNA sequencing. Journal of Molecular Biology 143, 161178.

Schultz, S. C., Dalbadie-McFarland, G., Neitzer, J. J. \& RICHARDS, J. H. (1987). Stability of wild type and mutant RTEM- $\beta$-lactamases: effect of the disulfide bond. Proteins: Structure, Function and Genetics 2, 290-297.

SHmotsu, H. \& HeNNER, D. J. (1986). Modulation of Bacillus subtilis levansucrase gene expression by sucrose and regulation of the steady-state mRNA level by sac $U$ and sac $Q$ genes. Journal of Bacteriology 168, 380-388.

StrinMeTZ, M., Le COQ, D., Ben DJemia, H. \& GAY, P. (1983). Analyse génétique de sacB, gène de structure d'une enzyme secrétée, la lévane-saccharase de Bacillus subtilis. Molecular and General Genetics 191, 138-144.

Steinmetz, M., Le COQ, D., AYMerich, S., GonzyTreboul, G. \& GAY, P. (1985). The DNA sequence of the gene for the secreted Bacillus subtilis enzyme levansucrase and its genetic control sites. Molecular and General Genetics 200, 220-228.

Virira, J. \& Messing, J. (1982). The pUC plasmids, an M13mp7-derived system for insertion mutagenesis and sequencing with synthetic universal primers. Gene 19, 259-268.

WiCKNER, W. T. \& LoDish, H. F. (1985). Multiple mechanisms of protein insertion into and across membranes. Science 230, 400-407.

Yutani, K., Ogasahura, K., Tsujtta, T. \& Sugino, Y. (1987). Dependence of conformational stability on hydrophobicity of the amino acid residue in a series of variant proteins substituted at a unique position of tryptophan synthase $\alpha$ subunit. Proceedings of the National Academy of Sciences of the United States of America 84, 4441-4444.

ZOLLER, M. J. \& SMTT, M. (1984). Oligonucleotide directed mutagenesis: a simple method using two oligonucleotide primers and a single-stranded DNA template. DNA 3, 479-488. 